\title{
Personality Traits, Entrepreneurial Self Efficacy And Financial Capability Effects On Entrepreneurial Intention
}

\author{
Ade Maharini Adiandari, Yuliani, Hendra Winata
}

\begin{abstract}
This study objectives to show the effect of personality traits on entrepreneurial target by using entrepreneurial self-efficacy as a mediating variable and the financial capability as a moderating variable. The research was conducted on students as representatives of the young generation. Currently, many regions need the creation of new economic resources to improve the community welfare where one of the strategies is by creating young entrepreneurs. For that reason, the involvement of higher education institutions in shaping the student's mindsets and encouraging their entrepreneurial intention is very important.

This study focuses on personality traits accompanied by incorporating elements of entrepreneurial self-efficacy and financial capability as variables that are believed to play a role in encouraging student entrepreneurial objective as a representative of the young generation. The study involved 112 students of the Faculty of Economics who were undergoing their third year of education at the University of Ngurah Rai, Denpasar, Bali. Data was collected through questionnaires and processed using SPLS statistical tools.
\end{abstract}

The findings illustrates that personality traits and entrepreneurial self-efficacy have an important influence on entrepreneurial goal. The discoveries also produce evidence that financial capability does not moderate the effect of personal behaviors on entrepreneurial target, which means that if someone does not have a financial capability, it will not prevent him from entrepreneurship because he has personality traits and/or self-efficacy as an entrepreneur. This finding also shows that higher education institutions could play a part in shaping personality traits and student entrepreneurial self-efficacy early with the preparation of a comprehensive curriculum between theory and practice in order to be able to encourage entrepreneurial intention after students graduate from their college.

Index Terms: Entrepreneurial Intention, Personality Traits, Entrepreneurial Self Efficacy, Financial Capability.

\section{INTRODUCTION}

Entrepreneur sector development highly necessary to improve social welfare, including in Indonesia. Many research evidence that entrepreneurship could become key to indicate improvement toward society welfare indicators such as economic growth, low unemployment rate and technological modernization (Baumol, 2007). One of the initiations of global entrepreneurship research is carried out by the Global Entrepreneur Monitor (GEM) consortium. This consortium is a global network, covering more than 100 countries and conducting entrepreneurial research using

Revised Manuscript Received on April 19, 2019.

Ade Maharini Adiandari, Universitas Ngurah Rai, Denpasar, Bali, Indonesia(Email: maharini.adiandari@unr.ac.id).

Yuliani, Universitas Sriwijaya, Palembang, Indonesia,(Email yulianisyapril@unsri.ac.id).

Hendra Winata, Universitas Brawijaya, Malang, Indonesia(Email winatahendra@student.ub.ac.id). the GEM entrepreneurial model. The GEM model produces indicators of entrepreneurship, both at the specific and national levels that can be compared between countries. on the basis of information from the Global Entrepreneur Monitor (GEM, 2016), the number of new business ownership rates represents data ratio of the adult population aged among the ages of 18 and 64 years who are in the method of starting a business which is less than 42 months old shows improved numbers. The new business ownership rate is $7.7 \%$ for Africa, $6.1 \%$ for Asia \& Oceana, 7.4\% for Latin America \& Caribbean, 3.4\% for Europe and 5.5\% for North America. Indonesia in the Asia \& Caribbean region has a figure of $10.4 \%$ (GEM, 2016). This shows the development of a new business ownership rate that is quite good in Indonesia, although this figure is still below several other Asian countries such as Thailand with $12.6 \%$ and Lebanon $12.1 \%$. Furthermore, this shows how important it is to encourage the increase of entrepreneurial intention in Indonesia to improve people's welfare.

In terms of entrepreneurial intention number improvement in Indonesia, Indonesia has quite an enormous opportunity, particularly viewed from its demographic and total productive population sides. One of an interesting issue for the past few years is entrepreneurial intention development through the role of higher education institutions. Alongside such issue, the education sector has taken a crucial role in entrepreneurial intention, one of them indicated by the rapid development of researches concerning entrepreneurship involving educational institution. These indicate a high chance of conducting awareness and entrepreneurship interest development since the beginning of the young generation for nation advancement.

Research concerning entrepreneurship interest on the young generation, particularly in higher education scope involving students across the globe as a respondent has encountered excellent development. For instance, research conducted by Voda \& Florea (2019) which analyzes entrepreneurial targets, locus of control, success and entrepreneurial education in the terms of students in Romania, Choudhary (2017) who conducted research related to investigating entrepreneurial intention gene $\mathrm{Y}$ and focus on investigating the capacity of Australia vocational education student as representative of Generation $\mathrm{Y}$ in Australia to be entrepreneurial, which could fuel future economic development and Hattab (2014) focused to

Published By:

Blue Eyes Intelligence Engineering 
investigate the effect of entrepreneurship education on entrepreneurial targets of Egyptian higher institutes pupils from three faculties to initiate a different venture using Linen's model.

Based on such studies finding related to entrepreneurial intention, experts have identified several causes of low entrepreneurial intention on young generations. old studies on entrepreneurial objective have recognized 3 reasons that dominate entrepreneurial intentions as follows: the demographic profile, personality traits and contextual factor (Qosja \& Druga, 2015).

In order to develop research results and follow up on the differences in the results of research related to entrepreneurial intentions from several previous researchers which were seen in the development of research hypotheses in the review literature section, in this research we plan to re-analyze the consequence of persona behaviors on entrepreneurial intention. The scope of personality behaviors in this research is based on the psycho-behavioural traits of someone who has been studied by Popescu et al. (2016). Psycho-behavioural traits include creativeness, locus of control, the requirement for success and risk-taking tendency. As affect means of development from previous research, this study also included entrepreneurial selfefficacy variables as mediating variables and financial capability variables as moderating variables of the result of personality traits on entrepreneurial objectives.

\section{LITERATURE REVIEW}

\section{A. Entrepreneurial Intention}

Indonesian higher education institutions have evidenced to generate more graduates working as an employee compared than becoming an entrepreneur. This encouraged the researcher to ensure factors that could encourage Indonesian higher education graduates to have high entrepreneurial intention.

The entrepreneurial intention could be explained as a mental state and behaviour, directing and controlling the personal activities toward the improvement and implementation of new business ideas (Hattab, 2014). This entrepreneurial intention could also be defined as his/her assumed wish to launch a business or to form a different organization in the coming days (Gartner, 1988), commitment to start a new business (Krueger \& Carsrud, 1993). of the highly known theories are Theory of Planned Behaviour (Ajzen, 1991) and The Model of Entrepreneurship Event Theory or Shapero's Model (Ndaghu, Gwems, Wajiga, \& Vasumu Augustine, 2016). Ajzen Theory explained that entrepreneurial intention described by 1) individual behaviour toward attitudes; 2) subjective norms; 3) opinion of behavioural control. Meanwhile, Shapero's Model focused on 1) perception of desirability; 2) tendency to perform; 3) opinion of viability. In addition to both theories, several other theories development were explained by (Bird, 2015) in which entrepreneurial intentions development was first published by Bird in 1988 based on combination from social and personal context, then continued to develop in the Schlaegel
Several theories underlie entrepreneurial intention. Two

and Koenig models which elaborated the two intention creation processes, which together include attitudes, norms, self-efficacy and perceived behavioral control, perceived attraction and perceived feasibility.

Above mentioned developed theories model emerge many perception characters and driving factors attached to them to an individual in connection with entrepreneurial intention. On its development, many researchers remain sought to develop new models by combining several existing models based on issue development concerning entrepreneurship in practical concept. One of them is (Krueger, 2007) that explained that private or situational endogenous reasons affect the observed social standards and the observed advisability. Such a development effort eventually generated many studies. (Popescu, Bostan, Robu, Maxim, \& Diaconu (Maxim), 2016) mentioned that some of the studies refer to own factor of effect (cognitive approach) and others refer to environmental reasons, such as family and society (contextual approach). The present study relies on the use of the Theory of Planned Behavior that focuses on personal traits influence entrepreneurial intention while investigating self-efficacy as a mediating variable and financial capability as a moderating variable. Relationship pattern from this research variable explained as follow.

\section{B. Personality Traits and Entrepreneurial Intention}

As previously mentioned, many research results emerged from previously existing models development process including personality traits effect on entrepreneurial intention model (Karimi et al., 2017) described that personality behaviors and contextual factors consequence on entrepreneurial objective, (Uddin \& Bose, 2012) discovered the direct connection among personality behaviors and goal. (Popescu et al., 2016) explained link among personality traits and entrepreneurial intention of the Romanian Students, (Park, 2017) discovered entrepreneurship as a reference to personality traits partially acceptable on entrepreneurial intention. Interesting matter from (Park, 2017) research is that two of three personality traits elements did not affect the entrepreneurial target. Such two elements are innovation and risk-taking, meanwhile, the other factor, proactive, affected entrepreneurial purpose. This research desired to test personality traits effect on the entrepreneurial target further. Personality traits indicators used based on individual psycho-behavioural traits that (Popescu et al., 2016) ever examined. Such Psychobehavioural traits comprised of creativity, locus of control, the requirement of success and danger taking propensity.

H1: Personality Traits have a positive effect on entrepreneurial intention.

\section{Personality Traits and Entrepreneurial Self Efficacy}

In a research done by May et al. (2017) stated that at present entrepreneurial self-confidence has their abilities within certain entrepreneurial activities such as discussing, working together, advertising, managing, innovating well. The results of other studies display personality traits have an 
important effect on entrepreneurial self-efficacy. For example, Emotional Constancy, Conscientiousness, Agreeableness (Wang et al., 2017, Karwowski et al., 2013) and marketing, innovating, managing, danger taking and monetary controlling (Chen et al., 1998). For this reason, this research will reconsider the effect of personality traits on entrepreneurial self-efficacy, which gives rise to the another hypothesis.

H2: Personality Traits have a positive effect on Entrepreneurial Self Efficacy

\section{Entrepreneurial Self-efficacy and entrepreneurial} intention

In the development of Theory of Planned Behaviour that he pioneered, (Ajzen, 2002) affirmed that self-efficacy is one of the action of perceived behavioural control that need to include. Self-efficacy itself identified as beliefs in individual's capability to start up and perform the progress of action needed to yield given achievements (Bandura, 1989). In entrepreneur context, self-efficacy mentioned as entrepreneurial self-efficacy (ESE) which defined as the degree to which a person believes that he/she could take the role and solve duty as an entrepreneur (Mcgee, Peterson, Mueller, \& Sequeira, 2009). In his study, (Bullough, Renko, \& Myatt, 2014) described that ESE consistently related to discovered that component within Theory of Planned Behaviour had a partial effect on entrepreneurial intentions including self-efficacy (Moriano, Gorgievski, Laguna, Stephan, \& Zarafshani, 2011) and self-efficacy did not significantly affect on entrepreneurial intentions (Ogunleye then researcher interested in using ESE as mediating variable on personality traits effect on the entrepreneurial objective. To get a complete picture, this research also directly tests the result of entrepreneurial self-efficacy on entrepreneurial intention.

H3: Entrepreneurial self-efficacy has a positive effect on entrepreneurial intention

H4: Entrepreneurial self-efficacy as personality traits effect mediation on entrepreneurial intention.

\section{E. Financial Capability and entrepreneurial intention}

In his study, (O’Donnell \& Keeney, 2010) mentioned that financial skill is a new idea which encompasses people's information and talents to realize their financial circumstance, along by the encouragement to take action. Further detail, (Atkinson et al., 2017) stated that the four domain of financial skill used in the UK study is capability related to managing money, planning forward, selecting products and staying educated. Such financial capability is crucial in managing daily financial activity and even for an entrepreneur in performing his/her business. Having excellent ability in managing business finance, believed capable of providing far better and consistent business result sustainability. old researches have demonstrated a positive relation among financial capabilities and performance (Singhry, 2015), but study concerning effect from financial capabilities and entrepreneurial intentions are still hardly encountered. One of the research in this area conducted by (Singhry, 2015) that discovered that there was a relation entrepreneurial intention. Meanwhile several researchers $\&$ Osagu, 2014). Based on these research results difference,

among financial capabilities and technopreneurship target. For this research development, then financial capability used as a moderating variable on personality traits effect on entrepreneurial intentions.

H5: Financial Capability as a moderating variable between the effect of Personality Traits on Entrepreneurial Intention.

\section{METHOD}

In order to examine personality traits effect on entrepreneurial targets by entrepreneurial self-efficacy as mediating variable and financial capability as moderating variable on personality traits influence on entrepreneurial intentions, this research used a five-point scale for the survey. There was 125 questionnaires distributed to thirdyear undergraduate program study students in University of Ngurah Rai Denpasar. From 125 questionnaires, 112 of them were filled and therefore could be used for further analysis. Smart PLS was used for empirical analysis. Figure 3.1 shows the research model on the basis of theory and hypothesis.

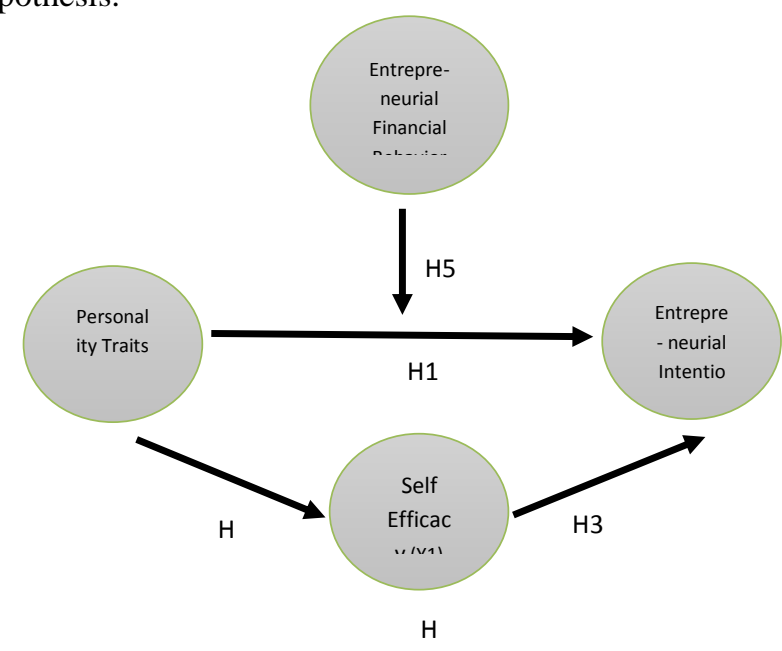

Fig 3.1: Research Model

This study was conducted in five stages. The first stage was a literature review to determine study dimension and indicator. The second was a measurement scale that would be used. The third stage would be reliability, validity and goodness of fit tests to determine whether or not the model was fit for further analysis. Hypothesis testing using Smart PLS constituted the fourth stage and ended by result and summary discussion.

\section{RESULT AND FINDING}

In this study, a series of reliability tests, validity, the goodness of fit models and hypothesis tests were conducted. An indicator deemed to have good reliability, if its outer loading or loading factor value higher than 0.70 , but on early stage, loading factor of 0.50 through 0.60 still deemed acceptable. Based on the above criteria, indicator by outer loading below 0.50 shall be dropped from the model. Test carried out using the following several tests, namely 
Convergent Validity, Discriminant Validity and Composite Reliability.

Convergent validity calculation aimed to discover instrument items that could be utilized as an indicator from entire latent variables. Convergent validity test result measured according to the loading factor (outer loading) value from latent indicator (construct). Convergent validity testing result by outer filling value below 0.50 shall be dropped from the model. The initial test results show that not all indicators have an outer loading value above 0.60 from the model. After that, the data is then re-tested to obtain indicators that meet the appropriate convergent validity criteria. The results of the test again convergent validity could be viewed as a visualization of Table 4.1.

Table 4.1. Convergent Validity Testing Result

\begin{tabular}{|l|l|l|l|}
\hline Variables & Indicator & $\begin{array}{l}\text { Outer } \\
\text { Loading }\end{array}$ & Remarks \\
\hline X1 & $\mathrm{X} 1.1$ & 1.000 & Valid \\
\hline & $\begin{array}{l}\mathrm{X} 1.1^{*} \mathrm{Y} 1 . \\
2\end{array}$ & 1.000 & Valid \\
\hline $\mathbf{X 2}$ & $\mathrm{X} 2.1$ & 0.765 & Valid \\
\hline & $\mathrm{X} 2.2$ & 0.689 & Valid \\
\hline Y2 & $\mathrm{X} 2.3$ & 0.829 & Valid \\
\hline & Y1.2 & 0.890 & Valid \\
\hline
\end{tabular}

Discriminant validity is a reflective indicator based on cross-loading with its latent variable. Another method is through comparing the square root of the average variance extracted (AVE) value of each construct, by correlation among other builds within the model. In connection with such matter, it is recommended for measurement value to be greater than 0.50 . The discriminant validity test results show all values of Average variance extracted (AVE) more than 0.50 . Therefore, it could be concluded that this measurement had to meet the Convergent Validity requirement according to the Average Variance Extracted (AVE) value.

Subsequently, discriminant validity testing result could view as the following Table 4.2.

Table 4.2. Discriminant Validity Testing Result

\begin{tabular}{|ll|}
\hline & The average variance extracted (AVE) \\
$\mathrm{X} 1$ & 1.000 \\
$\mathrm{X} 1 \cdot \mathrm{X} 2$ & 1.000 \\
$\mathrm{X} 2$ & 1.000 \\
$\mathrm{Y} 1$ & 0.582 \\
$\mathrm{Y} 2$ & 1.000 \\
\hline
\end{tabular}

Composite reliability testing aimed to test instrument validity within the research model. Test results show that composite reliability and Cronbach Alpha testing indicated the satisfactory value, with all latent variables, had been reliable as entire variable values had composite reliability and Cronbach Alpha $\geq 0,70$. In other words, the questionnaire used as an instrument in this result was valid or consistent. Therefore, it could be concluded that entire indicators truly became it's of each latent variable construct measure. Composite reliability testing result could be viewed as the following Table 4.3.

Table 4.3. Composite Validity Testing Result

\begin{tabular}{l|l|l|l}
\hline Variable & $\begin{array}{l}\text { Composite } \\
\text { Reliability }\end{array}$ & $\begin{array}{l}\text { Cronbachs } \\
\text { Alpha }\end{array}$ & Remarks \\
\hline $\mathbf{X 1}$ & 1.000 & 1.000 & Reliable \\
\hline $\mathbf{X 1} * \mathbf{X 2}$ & 1.000 & 1.000 & Reliable \\
\hline $\mathbf{X 2}$ & 1.000 & 1.000 & Reliable \\
\hline $\mathbf{Y 1}$ & 0.640 & 0.806 & Reliable \\
\hline $\mathbf{Y 2}$ & 1.000 & 1.000 & Reliable \\
\hline
\end{tabular}

The goodness of fit model examination within PLS could be viewed from predictive-relevance $\left(\mathrm{Q}^{2}\right)$ value. Calculation result indicated predictive relevance value of 0.9758 or high value, that model feasibly stated to have appropriate predictive value. Predictive-relevant value of $97,58 \%$ indicated that data diversity that could be described by the PLS model being built was 97,58\%. Meanwhile, the remaining $2,4 \%$ described by other variables (that had not been contained within the model) and error.

The next step is testing the inner model (structural model), which essentially consists of testing the hypothesis in the study. Hypothesis testing carried out using t-test (Tstatistic) on each through effect pathway partially. In addition to the direct effect, PLS also identify the indirect effect. The indirect effect between personality traits (X1) on entrepreneurial intention (Y2) through entrepreneurial selfefficacy (Y1). The following table 4.4 and table 4.5 explains the direct and indirect effect respectively.

Table 4.4. Hypothesis Testing Result within the Structural Model: Direct Effect

\begin{tabular}{lllll} 
& $\begin{array}{l}\text { Coeffi- } \\
\text { cient }\end{array}$ & $\begin{array}{l}\text { Standard } \\
\text { Error }\end{array}$ & $\begin{array}{l}\text { T } \\
\text { Statis- } \\
\text { tics }\end{array}$ & Remarks \\
\hline $\mathbf{X 1}$-> Y1 & 0.326 & 0.010 & $31.262^{*}$ & Significant \\
$\mathbf{X 1}$-> Y2 & 0.249 & 0.057 & $4.346^{*}$ & Significant \\
$\mathbf{X 1} * \mathbf{X 2}$-> & 0.030 & 0.082 & $0.363^{\mathrm{ns}}$ & $\begin{array}{l}\text { Not } \\
\text { Significant } \\
\mathbf{Y} 2\end{array}$ \\
$\mathbf{Y 1}$-> Y2 & 0.412 & 0.006 & $72.160 *$ & Significant \\
$\mathbf{X 1}$-> Y1 & 0.326 & 0.010 & $31.262^{*}$ & Significant
\end{tabular}


Table 4.5. SEM Result Structural Model: Indirect Effect

\begin{tabular}{|c|c|c|c|c|}
\hline \multirow{2}{*}{$\begin{array}{l}\text { Indirect } \\
\text { Innuence } \\
\mathrm{X} 1 \rightarrow \mathrm{Y} 1 \rightarrow \mathrm{Y}_{2}\end{array}$} & \multicolumn{2}{|c|}{ Direct Erfect Coeflicient } & $\begin{array}{l}\text { I } \\
\text { Statistics }\end{array}$ & Remarks \\
\hline & $\begin{array}{l}\mathrm{X} 1 \rightarrow \mathrm{Y} 1= \\
0.326^{*}\end{array}$ & $\begin{array}{l}\mathrm{Y} 1 \rightarrow \mathrm{Y} 2= \\
0.412^{*}\end{array}$ & 0.134 & $\begin{array}{l}\text { Significa } \\
\text { nt }\end{array}$ \\
\hline
\end{tabular}

Remarks: * significant, ns not significant

Based on outcomes of testing the hypotheses above, it could be concluded that direct effect testing between personality traits (X1) on entrepreneurial intention (Y2), yielded structural coefficient value of 0,326 , with $\mathrm{T}$ statistic of $31,262>1,96$. Therefore there was a major direct effect among personality traits on entrepreneurial intention. Positive structural coefficient indicated that both variables had a positive relationship. In other words, the stronger personality traits, the higher entrepreneurial intention would be, therefore accept hypothesis (H1). The stronger personality traits, the higher entrepreneurial intention. Personality traits of a person greatly influence entrepreneurial intention. Without having strong personality traits, then someone will feel hesitant to open a business continuously, and this will affect the high entrepreneurial intention. The outcomes of this research differ slightly from those of Popescu et al. (2016) where the main result of the research clearly illustrates that only the requirement for success and the propensity towards taking risks perform a significant part in defining the entrepreneurial target. This question items when taking data and processing data. To determine the level of strength of the respondent's personality traits, in this study respondents were given 15 questions with "yes" or "no" answers which reflected the four indicators, namely creativity, locus of control, the requirement of success and risk-taking. From the number of "yes" answers from all respondents, the researcher made a ranking with 5 rating scales where 1 to 3 "yes" answers were categorized as personality traits that were not very strong, then 4 to 6 "yes" answers meant personality traits were not strong, 7 to 9 "yes" means personality traits are strong enough, 10 to 12 "yes" answers mean strong personality traits and 13 to 15 "yes" answers mean the personality trait is very strong. In general, the outcomes of this research support the research of Karimi et al. (2015) and Uddin \& Bose (2012)

Based on direct effect testing between personality traits (X1) on entrepreneurial self-efficacy (Y2), yielded structural coefficient value of 0,249 , with $T$ statistic of 4,346>1,96. Therefore there was an important direct effect between personality traits on entrepreneurial self-efficacy. Positive structural coefficient indicated that both variables had a positive relationship. In other words, the stronger personality traits, the higher self-efficacy would be, therefore accept hypothesis (H2). With strong personality traits, it is believed that it can influence the belief that he is able to manage the business well, can face all risks that will be faced and can meet the set targets. Theoretically, individuals who generally have strong personality traits are not simply affected by negative issues, even in some hectic states. We argue that individuals by a strong level of personality traits will be able to penetrate the dilemma when difference is probably caused by differences in how to treat

they are faced with uncomfortable situations that form higher entrepreneurial self-efficacy. Generally, the outcomes of the researchsupport some of the outcomes of previous studies (Chen et al., 1998; Wang et al., 2015; Karwowski et al., 2013).

Direct effect testing among entrepreneurial self-efficacy (X1) on entrepreneurial target (Y2), yielded structural coefficient value of 0,412 , with $\mathrm{T}$ statistic of $72,160>1,96$. Thus, there was a substantial direct effect between personality traits (X1) on entrepreneurial intention. Positive structural coefficient indicated that both variables had a positive relationship. In short, the higher entrepreneurial self-efficacy, the higher entrepreneurial intention would be, therefore accept hypothesis (H3). The high entrepreneurial self-efficacy of someone is believed to be able to encourage someone's entrepreneurial intention. Conversely without high entrepreneurial self-efficacy, we could be sure someone will feel insecure, and experience anxiety and fear could not succeed before actually trying. The lack of desire to try could show no interest in opening a business. This outcome supports the research of Bullough et al. (2014), which states that entrepreneurial intention is consistently related to entrepreneurial intention. However, the outcomes of this research do not support the study conducted by Ogunleye (2014) where entrepreneurial self-efficacy does not significantly affect entrepreneurial targets

The indirect effect between personality traits (X1) on entrepreneurial intention (Y2) through entrepreneurial selfefficacy (Y1), yielded indirect effect coefficient of 0.134 , then it could be concluded that there was significant indirect influence among personality traits (X1) on entrepreneurial target (Y2) through entrepreneurial self-efficacy (Y1). Coefficient had a positive sign, which means the higher the personality traits, it would affect the entrepreneurial target (Y2) higher through entrepreneurial self-efficacy. Therefore, accept hypothesis (H4). From the indirect test results between personality traits on entrepreneurial intention shows that someone who has strong personality traits can be said to have high entrepreneurial intention. This is natural, but most likely, it will not happen if a person does not have high entrepreneurial self-efficacy that he will be capable of managing his business properly. Thus personality traits can influence entrepreneurial intention if they have high entrepreneurial self-efficacy, so that entrepreneurial variable self-efficacy is a mediating variable but is partially mediated. It is said to be a partial mediation variable because of the coefficient results of a significant indirect effect between the influence of personality traits on entrepreneurial self-efficacy and entrepreneurial selfefficacy on entrepreneurial target. In addition, the path coefficient of direct influence between personality traits on entrepreneurial target is also significant.

Entrepreneurship financial capability effect testing as personality traits affect moderation on entrepreneurial intention, yielded structural coefficient value of 0,030 with $\mathrm{T}$ statistic of $0,363<1,96$. Therefore there was no entrepreneurship financial capability effect as personality 
traits moderation on entrepreneurial intention. Therefore, reject the hypothesis (H5). The stronger the personality traits of a person, then rationally it can be said that the entrepreneurial intention will be higher. From this study, it was found that in conditions where a person with strong personality traits without being accompanied by good financial capability, he still has high entrepreneurial intention. In this study, the financial capability variable is not a moderating variable. The outcomes of previous studies related to the role of financial capability variables as a moderating variable between personality traits to entrepreneurial intention are still very rarely found even by the author. One study that has been found is that there is a significant direct influence among financial capability variables on entrepreneurial intention (Barau, 2015).

\section{CONCLUSION}

Entrepreneurship is one way out to be able to create a young generation that is independent and able to create jobs. The creation of more quality jobs is done by developed countries around the world because with the ability to create quality jobs; it will be able to overcome economic problems that have an impact on improving the welfare of the people of a country. For this reason, it is very important how a country can create a young generation that has a strong entrepreneurial spirit that can create quality jobs. Moreover, the conditions in which the current generation of the world is in the midst of the 4th Industry. This means that the young generation, especially in Indonesia, must be prepared to face global competitiveness with other countries in the world. In this case, the part of higher education institutions is very significant in encouraging the interest in entrepreneurship of the young generation through the education system that has an impact on the output of graduates who have a strong entrepreneurial spirit.

This research is conducted to see the effect of personality traits as a representation of entrepreneurial spirit on entrepreneurial target. As a development, in this study using entrepreneurial self-efficacy as a mediating variable and the financial capability as a moderating variable.

The findings display that personality traits have a important impact on entrepreneurial objective, as well as entrepreneurial self-efficacy that has a helpful effect, both directly and indirectly on entrepreneurial intention. The part of entrepreneurial self-efficacy is as a partial mediation variable. The findings also produce evidence that financial capability does not moderate the influence of personality traits on entrepreneurial target, which means that if a person does not have a financial capability, then it will not hinder someone's entrepreneurial intention. This finding also shows that higher education institutions could influence in shaping personality traits and student entrepreneurial self-efficacy early through the preparation of a comprehensive education system and leading to the increased ability of personality traits and high entrepreneurial self-efficacy.

\section{REFERENCES}

1. Abbasian, S., \& Yazdanfarm Darush. (2013). Article information: International Journal of Gender and Entrepreneurship, $\quad 5(2), \quad$ 157-173.
https://doi.org/http://dx.doi.org/10.1108/MRR-09-20150216

2. Ajzen, I. (2002). Perceived Behavioral Control, SelfEfficacy, Locus of Control, and the Theory of Planned Behavior. Journal OfApplied Social Psychology, 32(4), 665-683.

3. Ajzen, I. (1991). Theory of planned behavior Theory of planned behavior. Social Psychologyvolume I: Social Cognition and Social Perception, 211, 1-8. https://doi.org/10.1037/t15668-000

4. Ali, J., Zakaria, N., Jaganathan, M., Rashid, N. A. M., Yacob, P., \& Gorondutse, A. H. (2017). Determinants of entrepreneurial intention: Empirical insights from Malaysian undergraduate business students. International Journal of Economic Research, 14(19), 159-169.

5. Atkinson, A., Mckay, S., Collard, S., Kempson, E., Atkinson, A., Mckay, S., \& Collard, S. (2017). Levels of Financial Capability in the UK Levels of Financial Capability in the UK. Journal of Complilation, 0962(July), 954-962.

6. Bandura, A. (Stanford U. (1989). Self-efficacy: toward a unifying theory ofbehavioral change. Psychol, 84(84), 191-215.

7. Baumol, W. J., \& Strom, R. J. (2007). Behavioral and cognitive factors in entrepreneurship. Strategic Entrepreneurship Journal, 1(1), 233-237. https://doi.org/10.1002/sej

8. Bird, B. J. (2015). Entrepreneurial intentions research: A review and outlook. International Review of Entrepreneurship, 13(3), 143-168.

9. Bullough, A., Renko, M., \& Myatt, T. (2014). Danger zone entrepreneurs: The importance of resilience and self-efficacy for entrepreneurial intentions. Entrepreneurship: Theory and Practice, 38(3), 473-499. https://doi.org/10.1111/etap.12006

10. Choudhary, N. (2017). Investigating Entrepreneurial Intentions of Gen Y A Study of Australian Vocational Education Students. Retrieved from https://researchbank.swinburne.edu.au/file/67fd4d72ad30-4bbf-a942a99cbea1646f/1/nitu_choudhary_thesis.pdf

11. Gartner, W. (1988). "Who Is an Entrepreneur?" Is the Wrong Question. - who is an ent - lums.pdf. Entrepreneurship Theory and Practice. Retrieved from https://zabdesk.szabist.edu.pk/CoursePortFolioFiles/Mub in_1140_2758_1/who is an ent - lums.pdf

12. Hattab, H. W. (2014). Impact of Entrepreneurship Education on Entrepreneurial Intentions of University Students in Egypt. Journal of Entrepreneurship, 23(1), 1-18. https://doi.org/10.1177/0971355713513346

13. Indarti, N., \& Krinstiansen, S. (2018). DETERMINANTS OF ENTREPRENEURIAL INTENTION: The Case of Norwegian Students. Gadjah Mada International Journal of Business, 5(1), 79. https://doi.org/10.22146/gamaijb.5392

14. Izquierdo, E. (2008). Competing Models of Entrepreneurial Intentions: The Influence of Entrepreneurial Self-Efficacy and Attitudes. Internationalizing Entrepreneurship Education and Training, IntEnt 2008 Conference, 1-30. Retrieved from $\mathrm{http} / / / \mathrm{mbaadmin}$.americaeconomia.com/sites/mba.americ aeconomia.com/files/competing_models_of_entrepreneur ial_intentions.pdf

15. Izquierdo, E., \& Buelens, M. (2011). Competing models of entrepreneurial intentions: the influence of entrepreneurial self-efficacy and attitudes. International 
Journal of Entrepreneurship and Small Business, 13(1), 75. https://doi.org/10.1504/ijesb.2011.040417

16. Karimi, S., Biemans, H. J. A., Naderi Mahdei, K., Lans, T., Chizari, M., \& Mulder, M. (2017). Testing the relationship between personality characteristics, contextual factors and entrepreneurial intentions in a developing country. International Journal of Psychology, 52(3), 227-240. https://doi.org/10.1002/ijop.12209

17. Koekemoer, D. J., \& Kachieng'a, M. O. (2003). Technological entrepreneurship: financing new technology based enterprises in South Africa, 437-442. https://doi.org/10.1109/iemc.2002.1038472

18. Krueger, N. F. (2007). What lies beneath? The experiential essence of entrepreneurial thinking. Entrepreneurship: Theory and Practice, 31(1), 123-138. https://doi.org/10.1111/j.1540-6520.2007.00166.x

19. Krueger, N. F., \& Carsrud, A. L. (1993). Applying the theory of planned behaviour -. Entrepreneurship \& Regional Deveopment, 5(1993), 315-330.

20. Kusumajanto, D. D. (2015). The Role of Entrepreneurship Education and Self Efficacy in Shaping Student Interest in Doing Entrepreneurship, 7(28), 153158 .

21. Licht, A. N., \& Siegel, J. I. (2005). The social dimensions of entrepreneurship. Technovation, 25(8), 939-946. https://doi.org/10.1016/j.technovation.2004.02.003

22. Mcgee, J. E., Peterson, M., Mueller, S. L., \& Sequeira, J. M. (2009). Entrepreneurial self-efficacy: Refining the measure. Entrepreneurship: Theory and Practice, 33(4), 965-988. 6520.2009.00304.x https://doi.org/10.1111/j.1540-

23. Moriano, J. A., Gorgievski, M., Laguna, M., Stephan, U., \& Zarafshani, K. (2011). A Cross-Cultural Approach to Understanding Entrepreneurial Intention. Journal of Career Development, 39(2), 162-185. https://doi.org/10.1177/0894845310384481

24. Mwiya, B. M. K., Wang, Y., Kaulungombe, B., \& Kayekesi, M. (2018). Exploring entrepreneurial intention's mediating role in the relationship between self-efficacy and nascent behaviour: Evidence from Zambia, Africa. Journal of Small Business and Enterprise Development, 1-22. https://doi.org/10.1108/JSBED-03-2017-0083

25. Ndaghu, T. J., Gwems, J. A., Wajiga, H., \& Vasumu Augustine, M. (2016). Shapero's Model: A Veritable Tool for Explaining Entrepreneurial Intentions and Attitudes among Management Technology Students in Mautech Yola, Adamawa State, Nigeria. International Journal of Business and Management Invention ISSN (Online), 5(12), 2319-8028. Retrieved from www.ijbmi.org

26. O'Donnell, N., \& Keeney, M. (2010). Financial capability in ireland and a comparison with the UK. Public Money and Management, 30(6), 355-362. https://doi.org/10.1080/09540962.2010.525004

27. Ogunleye, A., \& Osagu, J. (2014). Self-efficacy, Tolerance For Ambiguity And Need For Achievement As Predictors Of Entrepreneurial Orientation Among Entrepreneurs In Ekiti State, Nigeria - Academic Publications | Product details. European Journal of Business and Management, 6(17), 240-250. Retrieved from http://www.academicpublications.com/publication/p/620f6991ec416843/t/Self -efficacy,-Tolerance-For-Ambiguity-And-Need-ForAchievement-As-Predictors-Of-EntrepreneurialOrientation-Among-Entrepreneurs-In-Ekiti-State, Nigeria

28. Palamida, E. (2016). Determinants of entrepreneurial intentions: The interrelated role of background, situational and psychological factors. Doctoral
Dissertation, (May). $\quad$ Retrieved from https://theses.ncl.ac.uk/dspace/bitstream/10443/3299/1/P alamida\%2C 2016.pdf\%0Ahttp://libproxy.library.wmich.edu/login?url =https://search.proquest.com/docview/1913433098?acco untid=15099\%0Ahttp://primo-

pmtna01.hosted.exlibrisgroup.com/openurl/01WMU/01 WMU

29. Park, C. (2017). A study on effect of entrepreneurship on entrepreneurial intention. Asia Pacific Journal of Innovation and Entrepreneurship, 11(2), 159-170. https://doi.org/10.1108/apjie-08-2017-024

30. Popescu, C. C., Bostan, I., Robu, I. B., Maxim, A., \& Diaconu (Maxim), L. (2016). An analysis of the determinants of entrepreneurial intentions among students: A Romanian case study. Sustainability (Switzerland), 8(8), 1-22. https://doi.org/10.3390/su8080771

31. Qosja, E., \& Druga, E. (2017). Entrepreneurial spirit and factors affecting it: Case study based on the students of the European University of Tirana. International Journal of Social Sciences and Education Research, 1(3), 680691. https://doi.org/10.24289/ijsser.279146

32. Shinozaki, H., Ishida, M., \& Okamoto, T. (1986). Acromelic acid, a novel excitatory amino acid from a poisonous mushroom: effects on the crayfish neuromuscular junction. Brain Research, 399(2), 395398. https://doi.org/10.1016/0006-8993(86)91535-0

33. Singhry, H. B. (2015). The Effect of Technology Entrepreneurial Capabilities on Technopreneurial Intention of Nascent Graduates. European Journal of Business and Management, 7(34), 8-20. Retrieved from www.iiste.org

34. Uddin, M. R., \& Bose, T. K. (2012). Determinants of Entrepreneurial Intention of Business Students in Bangladesh. International Journal of Business and Management, https://doi.org/10.5539/ijbm.v7n24p128

35. Vodă, A., \& Florea, N. (2019). Impact of Personality Traits and Entrepreneurship Education on Entrepreneurial Intentions of Business and Engineering Students. Sustainability (Vol. https://doi.org/10.3390/su11041192 